\title{
Continuing Professional Development for the Personnel of Vocational School in Indonesia
}

\author{
E. Kosasih Danasasmita \\ Indonesia University of Education \\ kosdanasasmita@yahoo.co.id
}

\begin{abstract}
The need for skilled human resource in the new era globalisation is very important. The professional educator standards for vocational school is used by LPTK (Education Institutions of Education Workforce). The purpose of LPTK is to increase the skilled human professional educator by providing quality education to learners who possess keen interest, ability and talent in the technical and vocational fields. A teacher's profesionalism is acknowledged by having a certificate of profesional educator. As far, the relevan between certificate education for vocational school educators and proffesion education was given so different. An example the entitled pedagogic competence of vocational school teachers in building engineering is published as physics. It becomes so annoying and lack of continuing professional development. So far the certification process mentioned and classified by the Ministry of Education and Culture. The educator certificate is received through Professional Education of Teacher still can not be applied. Since it still it be done the effective and accurate of professional developing teachers for SMK's (Vocational School) personnel becomes so absurd. That's the reason continuing developing teachers for SMK's personnel need PPG as a classifier of processing certification teacher's profesionalism.
\end{abstract}

Index Terms - vocational school, TVET institution, continuing professional development.

\section{Introduction}

Indonesia is currently the fourth largest country in the world in terms of population (237.6 Mio inhabitants as of May 2010). 58\% of the population lives on Java, but the country is comprised of more than 17,500 islands inhabited by more than 6,000 . Archipelago stretches about $1,875 \mathrm{~km}$ from north to south and 5,000 $\mathrm{km}$ from west to east.

In education the Ministry of Education set up competence regulation and supervision of higher education. To manage TVET (Technical Vocational Education and Training), Vocational Education System in Indonesia consists of two parts, namely the system of vocational education (Vocational Education System), which is part of the National Education System is governed by the Education Act (Act No. 20/2003), and the system national training for work (national vocational training system Sislatkernas), regulated by the Labor Law (Law No. 13/2003) [1]. Education is a conscious effort to deliberately planned to achieve the intended purpose. In an effort to improve the quality of educational resources, teacher is a component of human resources should be built and developed continuously. Teacher professional development programs implemented through pre-departments or programs within the department. The teacher is one example of such type of profession, a job that requires professional training and mastery of specialized knowledge [2].

The basic concept of professionalism is the key to a professional, because this is what underlies a person to be able to be professional in their profession possessed. Teacher is one of the professions and the profession has grown to become a professional [3]. Because the demand for development and is in line with the educational system dynamics. Professionalism of teachers emphasizes mastery of science or management capabilities and its implementation strategy. Professionalism of teachers not only knowledge of technology and management but rather an attitude, professional development is more than a technician not only has a high skill but has the required behavior.

Attention to the quality of teachers in Indonesia, especially teachers of vocational much different from the teachers in the United States or Britain. In the United States the professional development of teachers must meet the standards referred to Stiles and Horsley (1998) and NRC (1996) that there are four standards of professional teacher development standards [4]-[5] .

Competencies required of teachers in performing their duties in a professional manner. The study of teacher education in the late 20 th century and early 21 st century indicate a growing phenomenon puts the teacher as a profession. Now notice that the real conditions of teachers as a profession, is no longer regarded as work (vocational) education requires a certain regular. The position is at least as can be seen from two sides, namely internal and external. Internally, there is a strengthening in social standing, protective position, income, and legal status. As the implications of this position, then externally occurs expectations and demands of the quality of the teaching profession, which is not only measured by the criteria of producer organizations (LPTK), but also according to the criteria of the user (users) among other professional associations, communities, and institutions that collect and provide income.

Teachers are one of the types of professional positions in the field of education. As a position, teachers must be prepared through education within a specified period with a set of courses and certain credit load in accordance with the hierarchy. Education is intended to educate prospective teachers who will be able to carry out his professional duties. Professional duties of teachers can be divided into four functions even in practice is an integral unified 
interrelated, support and strengthen one aspect against another. Four functions: 1) as a teacher educator, 2) the teacher as teacher, 3) teacher as coach, and 4) the teacher as a mentor.

Specialized in the formulation of teacher competency standards must first be reviewed, analyzed and discussed in depth all aspects related to the duties and functions of the teacher. Teacher Competency Standards Drafting Team Starter (SKGP) formulate teacher competence in 4 (four) clumps, namely: (1) Control Field of Study; (2) Understanding of Students; (3) Mastery Learning educate; and (4) Development of Personality and professionalism. Fourth clump reflects four teacher competency standards set out again each competency in grains are further broken down into indicators that serve to clarify the point of competence so that they can be called to develop teacher competency test instrument.

Certification is the process of obtaining a certificate of competence competencies of teachers that are meant to provide written evidence of the performance (performance) carry out the duties of teachers as the embodiment of their competence in accordance with the required standard of competence of teachers. Competency Certificate is a certificate of competence and evidence given only after the relevant graduate professional education of teachers of higher education institutions were selected. Certification of competence through professional education of teachers as quality assurance efforts of educators and education personnel in Indonesia means strategic and fundamental in improving the quality of teachers. Certification is a response to the need to improve the professional competence of teachers. Therefore, the process of certification of competence is seen as an important part in obtaining the necessary certificate of competence [6]-[7].

Law of the Republic of Indonesia Number 20 Year 2003 on National Education System, Article 61 paragraph (1) states that a certificate in the form of diplomas and certificates of competency; paragraph (2) diploma awarded to students in recognition of achievement of learning and / or completion of education after graduation examinations conducted by accredited educational unit; (3) Certificate of competency granted by the education and/or training institutions for students and community members in recognition of competence to perform a specific job after graduation competency test conducted by a unit of education or an accredited certification body. Related analysis is described and discussed in Refs [8]-[14].

From the above description, we can identify some of the problems associated with teacher certification program in Indonesia, among others:

1) What is the relationship between the national certification programs for teachers with the formulation of the four competencies of teachers who became one of the standards developed in Indonesia?

2) Will nationally certified teacher be able to improve the quality of the qualifications?

3) What is the function LPTK in the National Education Certification?

\section{Discussion}

\section{A. Professional Teacher}

Professionals derived from adjective meaning livelihoods qualified persons. In other words, work that is professional is a job that can only be done by those who are prepared for the job.

The teacher is a designation for the office, position, and profession for someone who devoted himself in the field of education through educational interaction patterned, formal, and systematic. In Law No. 14 Year 2005 on Teachers and Lecturers (Article 1) states that: "Teachers are professional educators with the primary task of educating, teaching, guiding, directing, training, assessing and evaluating learners in formal education, basic education and secondary education". Professional teacher will be reflected in the appearance of the implementation of the tasks marked with expertise in both the material and the method of learning. Expertise of professional teachers is skills acquired through a process of education and training that is specifically programmed. Formal recognition of the expertise expressed in the form of certification, accreditation, and licensing of the competent authority (in this case the government and professional organizations).

Professional teachers are people who have special expertise in Traffic or midwife teacher training (learning) so that it is able to perform its duties and functions as a learner with a maximum capability. Or in other words professional learners are educated and well trained and have rich experience in their field, meaning that a learner has acquired and mastered a variety of formal education in teaching and learning strategies, in addition to the professional learners must master the foundations of education competencies. The authority of the teacher is facing learners, for that he must have the ability and have a standard, with independent (autonomous) on scientific. So to work as a teacher need for formal recognition of the power through three stages namely certification, only registration and licensing.

a. Certification is a gift certificate that shows authority as the members of a particular person. Minister of Education will issue a ministerial regulation number 18 of 2007 which contains policies regarding teacher certification. Under the regulation, certification is carried out in the form of portfolio assessment is the recognition of the professional experience of teachers in the form of an assessment of the documents that describe: academic qualifications, education and training, teaching experience, planning and implementation of learning, assessment of superiors and supervisors, academic achievement, work of profession development, participation in scientific forums, field experiences of educational and social organizations, and awards relevant to the field of education.

b. Registration refers to an arrangement where the member name is required to be registered at an agency or institution

c. The license is a regulation that sets a person to obtain a permit from the authorities to run the job. 


\section{B. LPTK as Teacher Producer}

LPTK is one of the key success or failure of the education movement in order to meet quality standards, both standard products and standard of service and customer education is generally defined as a description of the success of education in changing the behavior of pupils /students who are associated with the national education goals. Nurulpaik $(2005,3)$ argues that we agree that prospective educators must be prepared in a professional manner in a particular conditioning settings, the educational environment are to be designed and prepared in such a way so as to form the expected character. According to Gaffar (2005: 3-4) that LPTKs has the main task to educate prospective teachers from kindergarten to college. Koesoema (2007) see education as a conscious effort aimed at the integral development of the human self and whole, through its various dimensions (religious, moral, personal, social, cultural, temporal, institutional, relational, etc.).

Education acts as a liaison two sides. On the one hand, individuals who are grown and on the other hand the social, intellectual and moral education to encourage the responsibility of the individual. Individual develops from birth and continues to grow. Education can also be defined as the process of socialization, namely socialization values, knowledge, attitudes and skills. So the conclusion that education is a conscious effort aimed at instilling individual sensitivity to social values, knowledge, skills and moral values in the society.

\section{Teacher Certification}

Efforts to ensure the quality of teachers in order to still meet the standards of competence the necessary existence of an appropriate mechanism teacher quality assurance should be developed based on a comprehensive assessment to produce a conceptual and empirical foundation, through the certification system. According Nataamijaya (2004) in Mulyasa (2008), certification is a procedure used by third parties to give written assurance that a product, process or service has met the requirements set.

Teacher certification is the fulfillment of the need to improve professional competence. Therefore, the certification process is seen as an essential part in the effort to obtain a certificate of competency in accordance with established standards. A teacher certification test process or competencies for prospective teachers who want to acquire or improve the recognition and appropriate competencies chosen profession. This certificate as proof of recognition of the competence of teachers who meet the standards of the teaching profession to do the work on the type and level of education teacher certification is an attempt to improve the quality of teachers is followed by an increase in the welfare of teachers, which is expected to improve the quality of learning and the quality of education in Indonesia on an ongoing basis (Depdiknas, 2008: 1). According Sujanto (2009) has a teacher certification purposes, among others, 1) Determining the eligibility of teachers as agents of learning. As a teacher means learning agents become actors in the learning process. Teachers who have received a teaching certificate means it deserves to be an agent of learning. 2)
Improve the process and the quality of education. The quality of education, among others, can be seen as a result of the quality of students' learning process. 3) Increase the dignity of teachers. 4) Increasing professionalism.

Professional teachers, among others, can be determined from the education, training, self-development, and other activities related to the profession. In addition to having goals, teacher certification also has benefits. The main benefit of certification is that 1) Protect from the teaching profession from harmful practices profession image a teacher. 2) Protect the public from the practice of educational and professional quality. 3) Increasing economic prosperity guru. For obtaining teaching certificate is not as easy as turning the palm of the hand, and requires the hard work of teachers. Certificates will be obtained teacher educators if they really have the competence and professionalism. For teachers who have the competence and professionalism, this probably is not a complicated issue, but a matter of time. Conversely, teachers who lack the competence and professionalism, this can be a thorny issue when it's turn to be certified has arrived. In connection with it, something that definitely was the teacher should prepare as early as possible to be certified, so a good chance does not go away because of the lack of preparation to be ready mentally scientific, and financial. In connection with the preparation in terms of science, teachers need to improve their competence and professionalism.

\section{Correlation between Professional Teachers and Teacher Certification.}

Professionals derived from an adjective which means of livelihood other words, professional job is a job that can only be done by those who are ready to work. In Law No. 14 Year 2005 on Teachers and Lecturers (Article 1) states that: "Teachers are professional educators with the primary task of educating, teaching, guiding, directing, training, assessing and evaluating students in formal education, on the basis of the level of education and secondary education".

Professional teachers are the ones who have the legal expertise in competency or midwife teaching (learning) until able to perform their duties and functions as a teacher with a maximum capacity. Or in other words, learners are educated and trained professionals and have rich experience in this field, which means that students have acquired formal education and master the various strategies in the teaching and learning activities, as well as professional learners also must control education in the platform of competence.

Certification is a gift certificate that shows authority as members of a particular certificate. Minister of Education will issue a ministerial regulation number 18 of 2007 which contains policies regarding teacher certification. Under this rule, a certification in the form of a portfolio that is recognition of the professional experience of teachers in the evaluation document that describes: academic qualifications, education and training, teaching experience, planning and implementation of learning, evaluation of superiors and supervisors, academic achievement, professional development work, participation in scientific 
forums, educational experiences and social organizations, and awards relevant to the field of education.

Realities faced by the author is a real problem when the author was a supervisor in each vocational schools in Bandung, one of the teachers there told the author that he was not in a good situation. He said that he graduated from the Teachers' Training College of Building Engineering Department (Pendidikan Teknik Bangunan), but when he gets professional teacher certification (Certificate educators) in writing that he is a Physics teacher. Because when handing Lesson Plans for Teachers certification requirements he wrote RPP (Lesson Plans) on statics, which is considered by Team of Assessor (Assessor) is a Lesson Plan for subjects Physics. Here lies the discrepancy between teachers and teacher certification, as described above, the teacher certification is the fulfillment of the need to improve professional competence. Therefore, the certification process is seen as an essential part in the effort to obtain a certificate of competency in accordance with established standards. A teacher certification test process or competencies for prospective teachers who want to acquire or improve the recognition and appropriate competencies chosen profession why in this case a Professionals (according to the time the teacher has been teaching for more than 15 years) but after following his teacher certification did not will understand what he gets (Certification of Educators) for the Certification of Teachers he called a Physics teacher professional? whereas during more than the 15 years he has taught Engineering Building, as Team appraiser wrong?. Or cannot distinguish between "statics" in PHYSICS and "statics" in VOCATIONAL SCHOOL?

So LPTK (Education Institutions of Education Workforce) role as described above, sustainable teacher profession development seem to just "Lip Service" because it was never involved in determining whether a teacher's professional or not? The teacher certification process is a process for printing professional teachers so "Teacher Producer" in this case actually LPTKs need to be involved in order to the teachers who will get a teaching certificate is really a teacher who is able to work professionally in his field.

\section{Conclusions}

1) Professional teachers are people who have special expertise in traffic or midwife teacher training (learning) so that it is able to perform its duties and functions as a learner with a maximum capability.

2) LPTK (Education Institutions of Education Workforce) has a very important role in preparing teachers professionals. This is because, LPTKs (Education Institutions of Education Workforce) those prospective educators must be prepared in a professional manner in a particular conditioning settings, the educational environment are to be designed and prepared in such a way so as to form the expected character.

3) The certification process is seen as an essential part in the effort to obtain a certificate of competency in accordance with established standards. A teacher certification test process or competencies for prospective teachers who want to acquire or improve the recognition and appropriate competencies chosen profession. This certificate as proof of recognition of the competence of teachers who meet the standards of the teaching profession to do the job.

\section{References}

[1] http://nidausanah.blogspot.com/2014/04/implikasi-undang-undangguru-dan-dosen.html

[2] http://jurnal.untan.ac.id/index.php/jpdpb/article/ view/2358[3]

K. Charvat, Metaschools.Cz-Toward Teacher Competencies with Web 2.0, IEEE Trans on Education, 2010, pp $1-6$

[3] I G. A. K. Wardanti, Guru Sebagai Pekerja ProfesionaL, Jurnal Pendidikan ,UT, 2010

[4] Hesti Murwati, "Pengaruh Sertifikasi Profesi Guru Terhadap Motivasi Kerja Dan Kinerja Guru Di Smk Negeri Se-Surakarta", Jurnal Pendidikan Bisnis dan Ekonomi (Bise), 2013, Vol.1 No. 1.

[5] Sri Muryani, Entri Sulistari, Alex D Ch Mirakaho, "Identifikasi Kemampuan Mengembangkan Kurikulum Dalam Implementasi KTSP di Kalangan Guru SMK-BM di Kota Salatiga” , Artikel Jurnal Satya Widya, Nomor : 2 Volume 29

[6] B. Ogwo and E. Ede, "Training and Continuing Education Program in Nigeria's Informal Sector Automobile Industry". International Journal of Vocational Education and Training, 2009, Volume 17, Number 1 .

[7] Kristin Mangantibe, "Analisis Kompetensi Profesional Guru Di SMA Negeri 3 Manado". Jurnal Pendidikan Ekonomi, 2014, vol 2., no 3 .

[8] http://ejournal.unima.ac.id/index.php/jpe/article/ view/2319

[9] http://jurnal sdm.blogspot.com/2009/09/konsep-kompentensidefinisi.html

[10] Istamar Syamsuri, "Peningkatan Kompetensi Guru Untuk Meningkatkan Minat Siswa Pada Bidang MIPA, makalah", http://kappa.binus.ac.id/ wikariag0225/Pemakalah\%25202_PENIN GKATAN\%2520KOMPETENSI\%2520GURU...

[11] Purnamawati, "Peningkatan Kemampuan Melalui Pelatihan Berbasis Kompetensi (Competency-Based Training) Sebagai Suatu Proses Pengembangan Pendidikan”. Jurnal MEDTE , Oktober 201,1 Vol.3 No.2.

[12] E. Kosasih Danasasmita, "Preparing the Graduation Who Are Ready to Work: Challenges and Solutions". Indonesia: Proceeding of $1^{\text {st }}$ UPI International Conference on Technical Vocational Education and Training, 2010.

[13] Masriam Bukit, "Strengthening TVET Teacher's Education through Teacher-Industry Linkages". Indonesia: Proceeding of $2^{\text {nd }}$ UPI International Conference on Technical Vocational Education and Training, 2012. 